\title{
Nanoparticle Paclitaxel Ointment SOR007
}

National Cancer Institute

\section{Source}

National Cancer Institute. Nanoparticle Paclitaxel Ointment SOR007. NCI Thesaurus.

Code C146821.

A topical ointment composed of the water-insoluble taxane paclitaxel that has been processed to form uncoated nanoparticles, with potential antineoplastic activity. Upon topical administration of nanoparticle paclitaxel ointment SOR007 to the affected area, and following epithelial and dermal penetration, paclitaxel binds to tubulin and inhibits the disassembly of microtubules, which leads to the inhibition of cell division, thereby halting the proliferation of rapidly-dividing tumor cells. The nanoparticles in the nanoparticle paclitaxel ointment are produced through a specific proprietary submicron particle production. 